\title{
RePLITO
}

\section{Minor Citizens? Holocaust Memory and the Un/Making of Citizenship in Germany}

\section{Sultan Doughan ${ }^{1}$}

${ }^{1}$ Strassler Center for Holocaust and Genocide Studies, Clark University

Published on: Feb 04, 2022

License: Creative Commons Attribution 4.0 International License (CC-BY 4.0). 
Holocaust memory has become the pillar of liberal democracy in a re-nationalizing Germany. After the unification of both Germanies in 1990 and the surge in nationalist sentiments about who rightfully belongs to this new Germany, Holocaust memory emerged as a public frame of reference and gradually gave rise to museum and memorial spaces as part of a new official memory. Exhibiting and living with the ghosts of Germany's past meant that a certain threshold was reached, Germany had matured, had endured and ultimately triumphed over evil.

But after evil, did Germans change? If Jewish religious difference and claims to political equality was the bone of contention in modern Germany, is any of that more acceptable in post-Holocaust Germany? And does it matter if we are talking about Jewish religious difference specifically or any other form of ethnic, political or religious difference? Is the right to religious difference enabled by Holocaust memory? What is the relation between Holocaust memory and liberal democracy? In the German case, liberal democracy is a highly re-constructed political force of the post-WWII period. This reconstruction is tied to Allied-controlled ad hoc re-education of the political administration and bureaucrats, and the re-organization of certain key domains such as public school education. But beyond the Nazis of the 1930s and 1940s, how is Holocaust commemoration tied to education, citizenship and minority management? Allow me to take these questions into the domain of civic education, where I conducted research in sites of formal and informal education.

Civic education is a specific site and institution. As an institution, the Federal Agency of Civic Education is located within the Ministry of the Interior. As a specific site, it is governed by a logic that might not be easily transferable to education as such or to general social life. But this is not to say that the governing logic, one of soft-policing and self-disciplining, is detached from the larger phenomenon of how citizenship is practiced in public. Indeed, the site of civic education might provide a window for gauging broader social practices of how certain social segments and groups are more readily understood to be immature, dangerous or as not integrated, because of an "illiberal ideology." In other words, the reader might understand how certain groups and subjects are distinguished and governed, and in fact even produced, as not citizenly enough, as well as what kind of forms of speech and comportment are considered extreme and/or problematic behavior in a liberal democracy.

In this brief piece, I will try to outline how civic education has mobilized Holocaust memory for a range of pedagogical practices to ensure that Middle Easterners, i.e., 
descendants of former labor migrants and refugees, do not act out political rage or make provocative statements, including those that verbally target the state of Israel and that can be considered anti-Semitic in Germany. A major concern for me is first, the ways in which certain historical lessons out of German-Christian-Jewish relations after the Holocaust have been recast to become a tool of governance that minoritizes and racializes former immigrants/German-born/German-citizens of Middle Eastern descent as Muslims. The various ethnic and national Muslim communities are not governed as a minority nor do they have access to group-differentiated rights. Thus, I am not suggesting that Muslims are a minority, in a legal or ethnic sense. Rather, I am suggesting that a heterogeneous group of former immigrants are being governed by their actual or perceived religious difference as a problem to liberal democracy and secularism, which leads to my second concern. This perception of Middle Eastern immigrants, Palestinians specifically, as Muslims has further informed how certain speech forms and political demands during protests, especially with regards to IsraelPalestine, are not understood as a political problem, but rather as a religious problem rooted in traditional Islam endangering post-Holocaust liberal democracy. This reframing, I suggest, has further contributed to the regimentation of citizenship. Citizenship has been supplemented with additional pedagogical tasks, formal exams, informal workshops and seminars, and even with the threat of denationalizing citizens, if they engage in anti-Semitic acts. While any kind of physical and political violence should be condemned, and antisemitism in Germany cannot be taken lightly, it is curious to see that forms of "Muslim Antisemitism" seem to produce more drastic political formulations within the administrative institutions than simply Antisemitism, or even proven Neo-Nazi murders of Turks and others. Why is that?

Here I explore how citizenship has expanded in its pedagogical form without delivering on the promise of political equality. Concretely, I am interested in how German citizens of Middle Eastern descent are continuously taken to task as not being integrated enough and can be denied certain constitutional rights. I contend that Middle Easterners occupy an ambivalent position as minor citizens. My use of minor citizens is inspired by Cathy Park Hong's Minor Feelings (Park Hong_2021: 77), where she describes the impossibility of Asian-American equality in the US. This impossibility is managed by Asian-Americans themselves, who learn to accommodate injuries inflicted upon them by playing along within racist imaginaries of Asians. Park Hong's book aims at overturning "white innocence" in order to make racism known as a lived affective reality (Park Hong_2021: 77). Written as a personal memoir, Park Hongpoints out white innocence and (Asian) shame, "the flip side of innocence” (Park Hong_2021: 77). 
Shame, or being shamed, for Park Hong is part of racial relations and racism; she recounts how her parents were regularly condescended or mocked by white adults, as if they were children. She states that, "[o]ne characteristic of racism is that children are treated like adults and adults are treated like children" (Park Hong 2021: 77).

By thinking through some of the affective realities Middle Easterners live in, I intend to draw attention to how they are obstructed from growing up and into a position of political equality. Instead, Middle Easterners have to learn to accommodate German sentiments, affects and expectations. On the one hand, they are not governed as a religious minority or provided collective religious rights. Instead, they are asked to work on themselves in order to resemble the Christian-secularized majority in a range of issues, and specifically with regard to the figure of the Jew. On the other, their ethnic, legal, and class backgrounds predispose them to political experiences that cannot be easily folded into the ideals of liberal democracy. As minor citizens, they learn to manage external expectations in order to gain majoritarian approval; even if that means that certain injuries inflicted onto them have to be downplayed. Voicing injury and making political demands, especially passionately, is perceived as aggressive, irrational, hateful, immature and stemming from raw religious sentiments. But are Middle Easterners bound to remain minor citizens, because uncomfortable political demands that differ from majoritarian views, can only be understood as religiously rooted atavistic sentiments and therefore illegitimate? I use the term minor citizens, also because direct encounters with civic education projects occur as teenagers between the ages 12-18. These teenagers are not yet considered radicalized, as Islamic extremists, but perceptible to and malleable by combat ideology. What does this reveal about the promise of citizenship and its actual workings?

Current German statistics claim that most anti-Semitic attacks, physical, verbal and targeting Jewish communal property, are executed by right-wing extremists. In fact, violent right-wing extremists have also attacked Jewish, Muslim and immigrant communities indiscriminately, as the example in Halle (2019) shows. Let me take a step back, in order to show how Holocaust memory and civic education became interwoven. Consider, for example, right-wing extremism prevention projects picking up in the 1990s and targeting mostly lower-working class and jobless youth from East Germany. The civic education projects in the 1990s were meant to socialize youngsters into a Germany in which migrants, refugees and other non-Europeans were part of the social landscape. To be sure, there were non-German, non-white subjects in the GDR as well, but their presence was often denied and curtailed in public. 
The problem with "foreigners" (Ausländer) had peaked in the early 1980s in West Germany and gave rise to ongoing national discontent. Even if these "foreigners", such as former guest workers and refugees, were ultimately undesirable subjects, oftentimes tolerated with short-term residence visas, who should ideally return to their country of origin. Even if killing non-Germans, non-White populations, as neo-Nazis and skinheads did systematically in the 1990s and ongoing (Nobrega, Quent, and Zipf 2021), was not only uncivil and a crime; in this new historical moment in which Germany tried to embrace a healthy nationhood, it also triggered horrible memories of genocidal violence against European Jewry. According to the ministries, these youth, often actually minors, had to be re-educated and re-socialized into liberal democracy, in order to avoid further political violence against minorities and perhaps more importantly, to avoid public embarrassment of this new Germany as deeply racist and nationalist.

Political violence against minority groups in Germany is not new, but in this historical moment of the early 1990s, the memory of the Holocaust worked as a talisman or a guarantor that perhaps Germans could become a nation and embrace liberal democracy, as long as they remembered their worst manifestation of nationalism. What I have discussed thus far, as a national development of citizenship, also had an international dimension consequential for the politics of human rights. According to political theorist Robert Meister, the early 1990s and with that the end of the Cold War, have brought the memory of the Holocaust to the fore in ways that the evils of the Holocaust were perceived as having come to a closure. This closure, Meister stresses, turned the Holocaust into a paradigmatic and unreachable event, with which other mass atrocities and genocides were then compared. This comparison of other atrocities became a way to measure if the events required a political intervention now or not-yet. Yet this rationale contributed to an international political passivity when wars were raging and taking the toll on civilians in Bosnia or Rwanda. The political sense of "Never Again!" did not necessarily mean that genocides could not happen again, but rather that they should not reach the magnitude of the Holocaust (Meister 2011). The post-Holocaust in Meister's account then is not simply the time after the Holocaust, but an epistemic shift in political thought that something like the Holocaust cannot happen again.

Taking these insights into the national context of Germany could in fact help scholars see if former Middle Eastern immigrants, most of whom feel addressed and identify with the category of the Muslim, even in its currently racialized sense, are treated in ways that would honor the memory of German-Jews before the Holocaust. By honoring 
I mean acknowledging how German-Jews as a minoritized group in modern Germany reached Emancipation in 1871, but remained subject to assimilation, were socially pressured into religious conversion and were accused of having divided loyalties. Should not any of this be relevant for thinking about how differentiated and minoritized groups are treated in post-Holocaust Germany today? If the Holocaust can become the paradigmatic event in the politics of human rights, can the experience of the German-Jewish minority not similarly be considered a lesson for the politics of citizenship? Or is it rather that in a post-Holocaust Germany, and Europe, the history of European Jews has acquired a mnemonic status fully disconnected from the practice of minority and migration management? This idea that perhaps Muslims in Germany today share something with European Jews of the past has been entertained by other social scientists. The possible connection seemed terrifying to religious Muslims, because they still hope for a different future. They still believe they can become political equals.

Holocaust memory in a post-Holocaust Germany, however, has played out differently. Certainly, important political barriers were overcome in the late 1990s and early 2000s. The new German SPD-Green government acknowledged immigration as part of a permanent social fabric and conditional citizenship was introduced for German-born children of immigrant parents. In a way Germany, meaning governmental institutions, congratulated themselves for being tolerant. Perhaps Germans had become a bit too tolerant, as the Christian Democrats claimed in 2005, when they regained power and shifted their previous anti-Turkish migrant politics to the Muslim problem. The CDUled government initiated the new Migration Act in 2005, which gave rise to the National Integration Plan in 2005 and the German Islam Conference (DIK) in 2006.

In the years since 9/11, the German Ministry of the Interior defined traditional Islam as the ideological raw material that provided the source for Islamic extremism. According to the German government, similar to other European integration policies, Islam needed to be reformed and Muslims re-educated. Similar to other forms of political extremism right-wing or left-wing, Islamic extremism aimed at overthrowing liberal democracy, but had a different political aim; by introducing Shari'a it sought to replace the secular state. But different from other forms of political extremism, Islam was a religion, and the religion of former immigrant communities. Further, according to the German political institutions, overthrowing liberal democracy and replacing the secular state with Shari'a rule was not necessarily dependent on brute violence and could be operated by seemingly integrated and moderate Muslims, who took over key positions within the government akin to a Trojan horse. This state-sanctioned narrative 
has certainly contributed to a public discourse in which former Middle Easterners, as Muslims, are perceived as internal enemies.

Integration policies obligated Middle Easterners to engage in additional forms of selfdisciplining when it comes to working, residing and living in Germany. As part of this, citizenship tests were introduced with specific questions about proper conduct with regard to private life, sexual and religious difference. Preventive pedagogical practices and integration policies targeting Muslim youth specifically were introduced in 2009. Further, professional groups such as social workers and community organizers, who enter the job market by way of professional re-education, are similarly subject to additional civic education in order to strengthen their liberal democratic outlook. It is perhaps not surprising that most of these participants were often veiled women, born in the Middle East, who are rejected on the regular job market based on their religious visibility. In contrast, Middle Eastern youth, who are already born into legal German citizenship, are targeted in the site of school.

In Berlin, where I conducted my research in civic education projects funded to combat Islamic extremism, the majority of this target group was of Turkish and Palestinian descent. The civil society organizations claimed that they were not targeting Middle Easterners or Muslims, but rather a dangerous ideology that could take hold of disoriented and frustrated youth, who would blame others for their perceived discrimination. I was specifically interested in understanding how these programs walked a fine line between social integration of a disadvantaged immigrant group and combating political forms of extremism, including antisemitism. Antisemitism among these teenagers, which could also include criticism of Israel during wars in IsraelPalestine, or subsequent verbal attacks of a person perceived as Jewish, would be categorized as potential Islamic extremism. According to this logic, "Islamic Antisemitism" was emanating from traditional Islam and the traditional position of Jews therein as lesser subjects. The Federal Agency of Civic Education has prominently featured stories of the Mufti of Jerusalem Hajj Amin Al-Hussaini meeting with Adolf Hitler as the emblematic relationship between traditional Islam and fascism.

The civil society organizations I worked with did not necessarily operate with the term citizenship (Staatsbürgerschaft). Rather, the civic educators discussed attributes and characteristics of political subjectivity as having civil courage (Zivilcourage), as being tolerant, as having agency and defending democracy. These characteristics pointed to being the right kind of liberal democratic subject. This subject was to be made, rehearsed and performed, it was not simply there. The students were often presented 
with role plays, e.g., an angry mob mobilized against a mosque-building project. How would they, the students, reason and argue with the angry mob? How would they not spiral into counter-anger and violence, but instead remain calm and understand that Germans can be rightfully afraid of Islam? In most of the workshops I attended, the participants learned to internalize the pejorative views others had of them as Muslims. The different organizations had different ideas of what constituted tolerance, what constituted a liberal outlook, and even when agency was called for and necessary, but they agreed that Muslim religiosity, practiced or identified with, could lead to intolerant Islamic extremism. Islamic extremism did not only mean violent combat, but insisting on visible religiosity could be considered extremist. Put differently, wearing headscarves or long skirts could count as extreme behavior.

My closest interlocutors were the civic educators of Egyptian, Israeli, Kurdish, Palestinian, Syrian and Turkish backgrounds, who often themselves rehearsed and practiced being tolerant and defending liberal democracy. They would for example use the both-sides logic when talking about Israel-Palestine or make the quick move to also criticize their country of origin, in order to avoid a singling out. Their contention was that criticism of Israel could turn anti-Semitic and then take an actual Jewish person or community as its target. Among the civic educators, however, there were also those who could not fully make that connection and instead disconnected the criticism of Israel from actual Jewish persons or communities. Those civic educators were often of Palestinian descent and had a different story to tell, but they also had learned to keep it to themselves, because they feared for their public image as civic educators. Instead of civil courage, many of them learned to self-silence or to talk in whispers and cry behind closed doors, not knowing how to address the generationally transmitted experience of displacement they were feeling. Palestinians had to displace themselves from their own feelings. That is because feeling violated and threatened or claiming displacement as a Palestinian in those settings, could be read as claiming victim status vis-à-vis the figure of the Jew.

Civic education handbooks and teaching guides explained how German-Christians after WWII had often claimed victimhood, deflecting from the horrors of the death camps, the deportations, and the mass shootings that Jews had fallen victim to or witnessed. Historically, this insistence on German-Christian victimhood often went hand in hand with denial of the systematic genocide of European Jewry. Currently, Palestinians claiming victimhood when it comes to Israel-Palestine are seen as engaging in a similar reversal of the victims (Täter-Opferumkehr) a form of postHolocaust anti-Semitism (Sekundärer Antisemitismus) according to the civic education 
handbooks. What escapes from view in these discussions is how a historically shaped relationship to the Holocaust from a perpetrator perspective had become governmentally effective in silencing a political debate about the status of religious difference and about the complex relations that Middle Easterners, specifically Palestinians, have with the consequences of the Holocaust. Middle Easterners have to learn to speak, to feel and to act like the Christian secularized German majority and abjure ways that would paint them as traditional Muslims, even if what they have to say concerns the notion of political freedom, liberal democracy and minority rights.

In May 2021, during the latest war in Gaza, the discussions around Holocaust memory, antisemitism and citizenship took on another dramatic turn in Germany. This time the Ministry of Interior suggested that anti-Semitic attacks would be punished by denationalizing the culprits. The political conflict in Israel/Palestine is not the only source of violence that shapes debates about belonging and citizenship. As I have tried to show, right-wing extremist attacks that targeted Muslim and Jewish spaces have also shaken Germany. Although right-wing attacks have been bloodier, deadlier and keep growing, they have not caused German politicians to suggest denationalizing as a proportionate punishment. To my knowledge, denationalizing Middle Easterners based on antisemitism is not legally practiced yet. The experience of being socially lynched, accused of Islamism and being ostracized, however, is a reality my interlocutors in civic education lived with. Perhaps they knew that their position was that of a minor citizen, conditional upon emulating and accommodating majoritarian sentiments and expectations, shrouded in white innocence after crimes against humanity.

Further readings

Meister, Robert. 2011. After Evil. The Politics of Human Rights. New York: Columbia University Press.

Nobrega, Onur Suzan, Quent, Matthias, and Zipf, Jonas. 2021. Rassismus. Macht. Vergessen. Von München über den NSU bis Hanau: Symbolische und materielle Kämpfe entlang rechten Terrors. Bielefeld: transcript Verlag.

Park Hong, Cathy. 2021. Minor Feelings. An Asian American Reckoning. New York: One World. 


\section{Citations}

1. Hong, Cathy Park. 2021. Minor Feelings : A Reckoning on Race and the Asian Condition / Cathy Park Hong. Minor Feelings : A Reckoning on Race and the Asian Condition. Paperback edition. London: Profile Books. $\_$

2. Rassismus. Macht. Vergessen. : Von München über den NSU bis Hanau:

Symbolische und materielle Kämpfe entlang rechten Terrors (Edition 1). 2021. transcript Verlag. $\_$

3. Meister, Robert. 2011. After Evil : A Politics of Human Rights / Robert Meister. After Evil : A Politics of Human Rights. Columbia Studies in Political Thought/Political History. New York [u.a: Columbia Univ. Press. $\triangleq$ 